\title{
CHILD MARRIAGE CONDITIONALITY AND ITS DISPENSATION IN MAHKAMAH SYAR'IYAH ACEH, INDONESIA
}

\section{Raudhatul Jannah}

Faculty of Law, Syiah Kuala University, Indonesia

Jl. Putroe Phang No. 1 Darussalam, Banda Aceh, 23111

Tel./Fax: +62-651-7552295 e-mail: raudha.jnh@mhs.unsyiah.ac.id

\author{
M. Ya'kub Aiyub Kadir \\ Faculty of Law, Syiah Kuala University, Indonesia \\ Jl. Putroe Phang No. 1 Darussalam, Banda Aceh, 23111 \\ Tel./Fax: +62-651-7552295 e-mail: m.yakub.akadir@unsyiah.ac.id
}

\begin{abstract}
This research aims to explain the policy regarding the conditionality and its dispensation of child marriage and to find out the effectiveness of the Law Number 16 Year 2019 Concerning the Amendment of Law Number 1 Year 1974 Concerning Marriage Law as well as the implementation of child marriage conditionality in Aceh by analysing Mahkamah Syar'iyah decisions. This research uses normative empirical legal research which mostly discusses on the Marriage Law and focuses on the norms regarding the conditionality and its dispensation of child marriage that is regulated under the Marriage Law and the implementation in Aceh.
\end{abstract}

Keywords : Child Marriage, Children Rights, Legal problems, Mahkamah Syar'iyah.

\section{INTRODUCTION}

Through article 7(1) Law Number 1 Year 1974 Concerning Marriage Law, Indonesia once stipulated that the minimum age for girls to have marriage is 16 years old. However, the minimum age requirement was still considered as underage according to Law Number 35 Year 2014 on Children Protection that defined children as any person age under 18. Thus, many activists argue and fill the judicial review of the minimum age requirement in Marriage Law to the Constitutional Court of the Republic of Indonesia. After several considerations, finally through Constitutional Court Decree Number 22/PUU-XV/2017, the judges have agreed to escalate the minimum age requirement for girls before they are married. Corresponding to the Constitutional Court Decree, Indonesia's House of Representatives revised Indonesia Marriage Law Number 1 Year 1974 to be the Law Number 16 Year 2019 Concerning Marriage Law. Under article 7(1) of the recent Marriage Law, the minimum age requirement of men and women before marriage is similar which is 19 years old. ${ }^{1}$ 
However, article 7(2) of the Marriage Law stated that: "In the event of deviation from the age requirement as referred to in paragraph (1), the parents of the male and/or the parents of the female party can request dispensation to the Court on very urgent grounds accompanied by sufficient supporting evidence", which gives the chance for the underage couple to be married as long as they have permission from their parents and request dispensation to the court.

Furthermore, the explanation of the law clarifies that the meaning of "deviation" is only can be done by submitting a dispensation application by the parents of one or both parties of the prospective bride to the Religious Court for those who are Muslim and District Court for those who are not, if the male and/or female party are under 19 (nineteen) years old. Meanwhile the word "urgent" is any circumstance where the party has no other option to postpone the marriage. In addition, the meaning of "sufficient supporting evidence" under article 7(2) of Marriage Law is a letter of statement that proves that the bride's age is still under 19 years old and another statement letter from a healthcare professional that supports the statement of parents that the marriage is necessary and urgent to be conducted.

Nonetheless, despite of the progress that Indonesia's policy has created to increase the minimum age requirements for girls to get married under Indonesia Marriage Law, the number of child marriage still remain high and concerning due to the conditionality that allowed children to get married based on article 7(2) of Indonesia Marriage Law. In the past years, there has only been a minor decline of child marriage cases in Indonesia, where in 2017 it reached 11.54 percent, in 2018 the number was 11.21 percent and the decrease of percentage still continued in 2019 to 10.82 percent. $^{2}$ 
Despite the declining percentage of child marriage in Indonesia, there are some provinces with the increasing child marriage prevalence, and one of them is Aceh. Since 2006, Aceh has been committed to be a Child Friendly Province (Provinsi Layak Anak), in which it has to achieve 20 indicators within 5 cluster and one of them is to be free from child marriage. However, even though child marriage prevalence in Aceh is still below national average, the child marriage prevalence in Aceh must not be underestimated. Because from time to time, the percentage of child marriage in Aceh is still increasing despite of the fact that national percentage of child marriage is declining. The percentage reached 4.62 percent in 2017, 5.29 percent in 2018, and reached approximately 6.6 percent in 2019. That percentage is concerning because it has doubled the percentage of DKI Jakarta and DI Yogyakarta in total, in which both of the provinces only reached 3.1 percent in total as of 2019. The situation is worsening in 2020 where the percentage increased up to 6.59 percent of child marriage cases all around Aceh.

${ }^{1}$ Art. 7 Law Number 16 Year 2019 Concerning Marriage Law.

${ }^{2}$ Badan Pusat Statistik, UNICEF dan Kementerian PPN, Pencegahan Perkawinan Anak: Percepatan yang Tidak Bisa Ditunda, Jakarta: Universitas Indonesia, 2019, Page. 30-32. 


\section{RESEARCH METHODS}

This research uses normative empirical legal research. Normative legal research involves the study of the law as an object and removes any non-legal material from the scope of this research. In addition, Peter Mahmud Marzuki defines normative legal research as a process to find a legal rules, legal principles, and doctrines of the law to address the legal issues at hand. ${ }^{3}$ Meanwhile, empirical legal research focuses on the application of laws in society and describes how to investigate the roles of policies and other legal arrangements at play in society. ${ }^{4}$

The normative approach on this research mostly discusses the Law Number 16 Year 2019 Concerning the Amendment of Law Number 1 Year 1974 Concerning Marriage Law and focuses on the norms regarding the conditionality of child marriage that is regulated under the Marriage Law. Furthermore, the empirical method that researcher use is by conducting field study as supporting materials for this research. The activities are including but not limited to collecting and processing data from various stakeholders that are relevant to the research as well as interviewing them for the purpose of this research.

\section{FINDINGS AND ANALYSIS}

\section{Definition of Child Marriage}

According to Article 1 of the Law of the Republic of Indonesia Number 1 Year 1974 on Marriage, marriage is defined as a relationship of both body and soul between a man and a woman as husband and wife with the purpose of building a joyful and lasting family founded on a belief in God. ${ }^{5}$ Under article 7(1) of the Law Number 16 Year 2019 concerning Marriage, it is stated that the minimum age requirements of men and women to be legally married are similar which is 19 years old. In addition, Wirjono Prodjodikoro defines that marriage is an engagement, inner and outer on the ground of faith, between a man and a woman for living together after fulfilling certain conditions. ${ }^{6}$

Regardless the absence of legal definitions of child marriage in Indonesia, the interpretation of child marriage has been discussed in international and national forums. United

\footnotetext{
${ }^{3}$ Peter Mahmud Marzuki, Penelitian Hukum, Jakarta: Prenada Media, 2005, Page. 3.

${ }^{4}$ Frans L. Leeuw, Empirical Legal Research: A Guidance for Lawyers, Legislators and Regulators, the Hague: Maastricht University, 2016.

${ }^{5}$ Art. 1 Law Number 1 Year 1974 Concerning Marriage.

${ }^{6}$ Tengku Erwinsyahbana, "Sistem Hukum Perkawinan Pada Negara Hukum Berdasarkan Pancasila", Jurnal Ilmu Hukum, Vol. 3, 2012, Page. 7.
} 
Nations defined child marriage as an informal or formal marriage of a boy or a girl before 18 years old.

Furthermore, the United Nations also consider child marriage as a violation of human rights that massively happened across the globe. ${ }^{7}$ Indonesia through National Population and Family Planning Board (abbreviated as BKKBN), also defines child marriage as a mariage where one or both party is still in children age which is according to Law Number 35 Year 2014 Concerning Children Protection is 18 years old.

\section{The Conditionality of Child Marriage and Its Dispensation Under Article 7(2) of Indonesia Marriage Law}

Despite Article 7 of Indonesia Marriage Law that stipulated the minimum age requirements for boy and girl to legally get married is 19 years old with parents' permission, article 7(2) furthermore stated that: "In the event of deviation from the age requirement as referred to in paragraph (1), the parents of the male and/or the parents of the female party can request dispensation to the Court on very urgent grounds accompanied by sufficient supporting evidence" which gives the chance for the underage couple to be married as long as they have permission from their parents.

According to the clarification, the word "deviation" only can be done by submitting a dispensation application by the parents of one or both parties of the prospective bride to the Religion Court for those who are Muslim and District Court for those who are not, if the male party and women are under 19 (nineteen) years old. Meanwhile the word "urgent" is any circumstance where the party has no other option to postpone the marriage. In addition, the meaning of "sufficient supporting evidence" under article 7(2) of Marriage Law is a letter of statement that proves that the bride's age is still below 19 years old and another statement letter from a healthcare professional that supports the statement of the parents that the marriage is necessary and urgent to be conducted.

\section{Legality of Child Marriage in Indonesia According to Marriage Law}

Regarding the legality of marriage, article 50 of Indonesia Civil Code (Kitab UndangUndang Hukum Perdata) states that "All individuals, who intend to enter into matrimony with one another, must notify the official of the Civil Registry at the place of domicile of one of the

${ }^{7}$ UNICEF, "Child Marriage Around the World", $<$ https://www.unicef.org/stories/child-marriage-aroundworld> [Accessed on 07/01/2021] 
parties". Article 51 of Indonesia Civil Code also gives additional provision which is "the marriage shall be drafted in a marriage certificate by an official of the Civil Registry (Pegawai Pencatatan Sipil)." In addition, article 2(2) of Indonesia Marriage Law also stipulated "Every marriage shall be registered according to the regulations of the legislation in force."

Those regulations have explicitly required a couple to register their marriage in order to be legal. However, in order to have an official registration, both parties must reach a certain age before committing marriage. Hence, Indonesia Marriage Law has classified three layers of ages to conduct marriage and to be able to register the marriage, the classifications are as follows:

a. Based on article 6(2) of Marriage Law that discussed the requirements of marriage that stated "to marry a person who has not reached the age of 21 (twenty-one) years, the consent of both parents must be obtained." which means marriage without parents' permission can only be legal if both parties are 21 years old.

b. Based on article 7(1) of Marriage Law that stated "Marriage is only eligible between the man and woman that has reached the age of 19". Which means, if they are under 21 years old and want to get married with their parents' permission, the minimum age requirement for both parties to get married is 19 years old.

c. Based on article 7(2) of Marriage Law that stipulates "In the event of deviation from the age requirement as referred to in paragraph (1), the parents of the male and/or the parents of the female party can request dispensation to the Court on very urgent grounds accompanied by sufficient supporting evidence." Which gives conditionality for a person under 19 years old to legally experience and register their marriage as long as they could receive a dispensation from the court.

This condition is limited and can only be applied under two circumstances which are in a very urgent ground and have sufficient supporting evidence.

\section{Effectiveness of the Marriage Law and the Practice in Aceh}

Since 2006 Aceh has committed to be a Child Friendly Province (Provinsi Layak Anak) as regulated in Ministry of Women Empowerment and Children Protection Decree Number 2 Year 2009 Concerning Provinsi Layak Anak, in which it has to achieve 20 indicators within 5 cluster with the principle of non-discrimination, children's best interest, ensure the growth of the child and give children the chance to participate and take their voice into account. One of the clusters for Aceh to be the Provinsi Layak Anak is to be free from child marriage that could 
lead to another potential harms for children who experience it. Child marriage leads to human rights violation that targeted children as a vulnerable stakeholder. The human rights violation that is happening due to child marriage is including but not limited to violating the right to education, resulting to children who are married to be more likely to dropout from school, right to be free from poverty that creates more children labor due to their lack of education and ability which results to minimum salary and income, the rights of health that caused reproductive disease for the parents and also another disease such as stunting for the children. Furthermore, child marriage is also resulting to more probability of domestic abuse due to the vulnerability of children, making them more fragile if the other party takes a dominant part. All of those findings were also validated by the Head of Dinas Pemberdayaan Perempuan dan Perlindungan Anak (DP3A) Aceh.

All of those mentioned above are also not in line with the spirit of Sustainable Development Goals (SDGs) that were created by the United Nations (UN), particularly goals 5.3 that aims to eliminate all harmful practices, such as early, child, and forced marriage. In addition, the impacts of child marriage are also not in line with SDGs goal number 1 to end poverty, SDGs goal number 2 which discussed about zero hunger, SDGs goal number 3 about good health and well-being, SDGs goal number 4 regarding quality of education, SDGs goal number 5 about gender equality, and SDGs goal number 8 that discussed about decent work and economic growth.

Under the Marriage Law, the Government has an obligation to carry out socialization and guide the community in order to prevent child marriage. However, the implementation of the law is still considered ineffective since the child marriage prevalence is growing even higher in Aceh. In which, after the most recent marriage law increased the minimum age requirement to be 19 years old, the number of dispensation letter issued escalated almost quadruple to be 879 letters issued by Mahkamah Syar'iyah with the big three cities where the cases happen are in Sigli with 135 cases, Takengon with 127 cases, and Lhoksukon with 88 cases. Sadly, even though the minimum age requirement for females has escalated in the spirit to prevent child marriage, but there is none of the cities or regencies in Aceh that are free from child marriage cases in 2020. The reasons behind the court decision may be varied depending on the cases. The samples of Court Order that has issued dispensation letters for child marriage cases in Aceh are as follows: 
Table 1

Reasons the Dispensation Letter Issued Based on Mahkamah Syar'iyah Court Order (Source:

Direktori Putusan Mahkamah Agung $)^{8}$

\begin{tabular}{|c|c|c|c|}
\hline No. & Reasons & Court Order & Notes \\
\hline \multirow{12}{*}{1.} & \multirow{12}{*}{$\begin{array}{l}\text { Religious } \\
\text { Values }\end{array}$} & 196/Pdt.P/2020/MS.Lsk & \multirow{12}{*}{$\begin{array}{l}\text { The letter of dispensation was issued due to } \\
\text { the reason of preventing the acts that is } \\
\text { prohibited by religion regardless of the age } \\
\text { of both persons are still under } 19 \text { and the } \\
\text { lack of any letter of statement from } \\
\text { healthcare professionals as to support the } \\
\text { urgency of marriage that they want to } \\
\text { conduct. Ironically, all of the couple request } \\
\text { the dispensation letters after failed to } \\
\text { register their marriage in Office of Religion } \\
\text { Affairs (KUA) and did not know the } \\
\text { minimum age requirement to get married } \\
\text { beforehand. }\end{array}$} \\
\hline & & 63/Pdt.P/2020/MS.Bir & \\
\hline & & 048/Pdt.P/2019/MS.Snb & \\
\hline & & 16/Pdt.P/2021/MS.Skl & \\
\hline & & 9/Pdt.P/2021/MS.Skl & \\
\hline & & 10/Pdt.P/2021/MS.Skl & \\
\hline & & 5/Pdt.P/2021/MS.Skl & \\
\hline & & 67/Pdt.P/2020/MS.Skl & \\
\hline & & 64/Pdt.P/2020/MS.Skl & \\
\hline & & 72/Pdt.P/2020/MS.Bir & \\
\hline & & 59/Pdt.P/2020/MS.Bir & \\
\hline & & 1220/Pdt.P/2020/MS.Lsm & \\
\hline \multirow{4}{*}{2.} & \multirow{4}{*}{$\begin{array}{l}\text { Unintended } \\
\text { Pregnancy }\end{array}$} & 67/Pdt.P/2020/MS.Lsm & \multirow{4}{*}{$\begin{array}{l}\text { The dispensation letters issued due to } \\
\text { pregnancy that happened outside of } \\
\text { marriage. }\end{array}$} \\
\hline & & 7/Pdt.P/2021/MS.Sk1 & \\
\hline & & 65/Pdt.P/2020/MS.Skl & \\
\hline & & 0115/Pdt.P/2012/MS-Tkn & \\
\hline \multirow{2}{*}{3.} & \multirow{2}{*}{ Poverty } & 7/Pdt.P/2020/MS. Mrd & \multirow{2}{*}{$\begin{array}{l}\text { The parents requested dispensation letters } \\
\text { to conducted marriage as the reason to get } \\
\text { rid of poverty in their family. }\end{array}$} \\
\hline & & 66/Pdt.P/2020/MS.Skl & \\
\hline
\end{tabular}

${ }^{8}$ Direktori Putusan Mahkamah Agung, < https://putusan3.mahkamahagung.go.id/beranda.html $>$ [Accessed on 10/03/2021] 


\section{CONCLUSION}

Through article 7(1) Law Number 1 Year 1974 Concerning Marriage Law, Indonesia once stipulated that the minimum age for girls to have marriage is 16 years old. However, the minimum age requirement was still considered underage according to Law Number 35 Year 2014 on Children Protection that defined children as any person age under 18. Thus, many activists argue and fill the judicial review of the minimum age requirement in Marriage Law to the Constitutional Court of the Republic of Indonesia. After several considerations, finally through Constitutional Court Decree Number 22/PUU-XV/2017, the judges have agreed to escalate the minimum age requirement for girls to marry. Corresponding to the Constitutional Court Decree, Indonesia's House of Representatives revised Indonesia Marriage Law Number 1 Year 1974 to be the Law Number 16 Year 2019 Concerning Marriage Law. Under article 7(1) of the recent Marriage Law, the minimum age requirement of men and women before marriage are similar which is 19 years old. However, article 7(2) of the Marriage Law stated that: "In the event of deviation from the age requirement as referred to in paragraph (1), the parents of the male and/or the parents of the female party can request dispensation to the Court on very urgent grounds accompanied by sufficient supporting evidence." Which gives the chance for the underage couple to be married as long as they have permission from their parents and request dispensation to the court.

Furthermore, the implementation of the law is still considered ineffective since the child marriage prevalence is growing even higher in Aceh. In which, after the most recent marriage law increased the minimum age requirement to be 19 years old, the number of dispensation letters issued escalated almost quadruple to be 879 letters issued by Mahkamah Syar'iyah. Unfortunately, even though the minimum age requirement for females has escalated in the spirit to prevent child marriage, but there is none of the cities or regencies in Aceh that are free from child marriage cases in 2020. Thus, the harmony of regulations, constitutional principles of antidiscrimination as well as equality have combined to stand against and prevent child marriage.

Some further explanation from the samples above, according to Court Order of Mahkamah Syar'iyah Lhoksukon under Order Number 196/Pdt.P/2020/MS.Lsk, the letter of dispensation was issued due to the reason of preventing the acts that is prohibited by religion regardless of the age of both persons are still under 19 and the lack of any letter of statement from healthcare professionals as to support the urgency of marriage that they want to conduct. The same case also happened in Bireun, under Court Order Number 63/Pdt.P/2020/MS.Bir, the 
Mahkamah Syar'iyah judges also issued the letter of a girl aged 16 years old to be married with a man aged 26 years old for identical reason. Furthermore, similar reason also happened in Court Order Number 1220/Pdt.P/2020/MS.Lsm and 67/Pdt.P/2020/MS.Lsm in Mahkamah Syar'iyah Lhokseumawe. For another reason, Mahkamah Syar'iyah Takengon through Court Order Number 0115/Pdt.P/2012/MS-Tkn issued the letter due to the reason of the girl that was still 13 years old was pregnant outside of marriage. Moreover, economic status also became one of the factors causing child marriage, through Court Order Number 7/Pdt.P/2020/MS. Mrd, The judges from Mahkamah Syar'iyah Meureudu issued the dispensation letter due to the reason that both of the parents of the girl have passed away and she has no source of income. Based on the fact provided, in relation with article 7(2) of Marriage Law, the words "on a very urgent grounds" and "accompanied by sufficient supporting evidence" that can be the reasons of child marriage dispensation has been interpreted broadly by the judges of Mahkamah Syar'iyah in Aceh.

\section{BIBLIOGRAPHY}

Ahmad Saleh, 2020, "Mapping the Needs of Local Law in order to Create the Friendly District and City Area for Kids', Kanun Jurnal Ilmu Hukum, Vol. 22, No. 1.

Badan Pusat Statistik, “Jumlah Penduduk Menurut Kelompok Umur dan Jenis Kelamin”, 2019, https://www.bps.go.id/indikator/indikator/view_data_pub/0000/api_pub/58/da_03/1, Accessed on 14/12/2020.

Daniel Perlman, 2017, Understanding and Ending Child Marriage: Insights from Hausa Communities, The World Bank.

Julie Freccero, 2018, Toward an End to Child Marriage, UC Berkeley Law School: Human Rights Center, California.

Sonny Dewi Judiasih, 2018, "Women, Law and Policy: Child Marriage Practice in Indonesia", Jurnal Notariil, Vol 3, No. 1.

M. Yakub Aiyub Kadir and Firmanila, 2020, Reparating Women's Rights Violation Within Aceh Truth and Reconciliation Commission (TRC), Udayana Journal Law and Culture, Vol 4 (1), 21-38.

Noor Sidharta, 2017, "Laws of Ratification of an International Treaty in Indonesian Laws Hierarchy”, Constitutional Review, Vol. 3, No. 2.

World Bank, 2017, "Economic Impact of Child Marriage: Global Syntesis Report", International Center for Research on Women: World Bank Conference. 